\title{
Bifascicular Block by ECG Finding
}

National Cancer Institute

\section{Source}

National Cancer Institute. Bifascicular Block by ECG Finding. NCI Thesaurus. Code C71046.

An electrocardiographic finding comprising right bundle branch block and left anterior fascicular block, or right bundle branch block and left posterior fascicular block. Defects occurring in two of the three divisions of the conduction system of the heart are considered bifascicular blocks. Technically left bundle branch block may be considered a bifascicular block. 